\title{
The Possibility of a Fair Paretian
}

\author{
Howard F. Chang ${ }^{\dagger}$
}

In my preceding article, I respond to the claim that the weak Pareto principle implies welfarism. ${ }^{1}$ Louis Kaplow and Steven Shavell make this claim in a series of recent papers. ${ }^{2}$ In my article, I have consistently adopted the definition of welfarism that is standard among social choice theorists. ${ }^{3}$ Under this standard definition, welfarism "restricts the information that can be utilized in ranking social states to utility information corresponding to those social states." 4 In their prior writings, Kaplow and Shavell have indicated that they intend to refer to this same concept. ${ }^{5}$ They contrast

$\dagger$ Professor of Law, University of Pennsylvania Law School. I would like to thank Louis Kaplow and Steven Shavell for our many fruitful exchanges, which inspired numerous revisions in my original article that refined and clarified my arguments.

1. Howard F. Chang, A Liberal Theory of Social Welfare: Fairness, Utility, and the Pareto Principle, 110 YALE L.J. 173 (2000).

2. LOUIS KaPlow \& STEVen Shavell, ANY NON-INDividualistic SOCIAL Welfare Function VIOLATES tHE PARETO PRINCIPLE (Nat'l Bureau of Econ. Research, Working Paper No. 7051, 1999), forthcoming as Louis Kaplow \& Steven Shavell, Any Non-Welfarist Method of Policy Assessment Violates the Pareto Principle, 109 J. POL. ECON. (2001) (hereinafter KAPLOW \& Shavell, NON-INDIVIDUALISTIC]; Louis Kaplow \& Steven Shavell, The Conflict Between Notions of Fairness and the Pareto Principle, I AM. L. \& ECON. REV. 63 (1999) [hereinafter Kaplow \& Shavell, Conflict]; Louis KaPlow \& STEven Shavell, PRINCIPLes OF FaIRNess Versus Human Welfare: ON THE Evaluation of Legal POLICY 44 (John M. Olin Ctr. for Law, Econ., \& Bus., Harvard Law School, Discussion Paper No. 277, 2000), forthcoming in 114 HARV. L. ReV. (2001) [hereinafter KaPlow \& SHA vell, Human Welfare].

3. E.g., Amartya Sen, Utilitarianism and Welfarism, 76 J. PHLL. 463, 468 (1979) (defining "welfarism" as the view that "[t]he judgment of the relative goodness of alternative states of affairs must be based exclusively on, and taken as an increasing function of, the respective collections of individual utilities in these states").

4. ROBIN BOADWAY \& NEIL BRUCE, WELFARE ECONOMICS 143 (1984). Social choice theorists also use the term "strong neutrality" to refer to this concept. Id.

5. They express this concept in the same algebraic form in each of their papers. KAPLOW \& SHAVELL, NON-INDIVIDUALISTIC, supra note 2, at 2; Kaplow \& Shavell, Conflict, supra note 2, at $66 \mathrm{n} .5$; KAPLOW \& ShAVell, HUMAN WelFARE, supra note 2, at 20 n.31. In each paper, their algebraic expression indicates that social welfare is a function of only individual utility; no other variable appears as an argument in the social welfare function.

An ambiguity arises when Kaplow and Shavell, without making explicit any further assumptions, assert as an "observation" that their notion of welfarism is equivalent to the Pareto indifference rule. KAPLOW \& SHAVELL, NON-INDIVIDUALISTIC, supra note 2, at 2. Welfarism, as social choice theorists use the term, however, is not equivalent to the Pareto indifference rule unless one makes "quite demanding" assumptions. Chang, supra note 1, at 222 n.193; Amartya Sen, Social Choice Theory, in 3 HANDBOOK of MATHEMATICAL ECONOMICS 1073, 1155 (Kenneth J. Arrow \& Michael D. Intriligator eds., 1986). In their reply, Kaplow and Shavell state that if the Pareto indifference rule applies, then "there is no sense in which the notion of fairness 
welfarist theories with notions of "fairness," which "are based, at least in part, on factors unrelated to individuals' well-being" such that "knowledge of the effects of a legal rule on each individual's well-being will not generally be sufficient to assess the fairness of the rule." ${ }^{\prime \prime}$ Kaplow and Shavell use the terms "well-being" and "utility" as synonyms. ${ }^{7}$ They claim that "any conceivable notion of social welfare that does not depend solely on individuals' utilities" will sometimes violate the Pareto principle. ${ }^{8}$

In my article, I show that this claim, expressed without qualification, as Kaplow and Shavell state it, is false. I present a "conceivable notion of social welfare that does not depend solely on individual utilities" that complies with the Pareto principle. Under either $F^{*}$ or $F^{* *}$, the rankings of alternatives will depend on information other than individual utilities. This fairness information may include, for example, the source of the utility produced by each alternative, which would be relevant if our fairness criterion $F$ is liberal consequentialism. ${ }^{9}$ This information is necessary under $F^{*}$ or $F^{* *}$, because the rankings under each theory require the identification of the fairness optimum to partition the set of alternatives. If we change the fairness information corresponding to each alternative, then even if the utility information corresponding to each alternative remains unchanged, the fairness optimum changes, and thus so do our rankings. ${ }^{10}$ Therefore, the rankings are a function of information other than individuals' utilities.

Thus, contrary to the claim in the title of one of their forthcoming pieces, Kaplow and Shavell do not show that "Any Non-Welfarist Method of Policy Assessment Violates the Pareto Principle." "11 They do not (and

is receiving any independent weight." Louis Kaplow \& Steven Shavell, Notions of Fairness Versus the Pareto Principle: On the Role of Logical Consistency, 110 YALE L.J. 237, 241 n.10 $(2000)$. This statement, however, is true only in the context in which everyone is indifferent between the alternatives in question. The premise that fairness information is irrelevant in that particular context does not imply that fairness information is irrelevant outside that context. Thus, Kaplow and Shavell cannot derive welfarism from the Pareto indifference rule without also assuming that an independence condition applies over an unrestricted domain. See BOADWAY \& BRUCE, supra note 4, at 143-44; Sen, supra, at 1122.

6. Kaplow \& Shavell, Conflict, supra note 2, at 65; see KAPLOW \& SHAVELl, HUMAN WELFARE, supra note 2, at 35 ("Notions of faimess have the property that evaluations relying on them are not based exclusively ... on how legal policies affect individuals' well-being.").

7. Kaplow \& Shavell, Conflict, supra note 2, at 66 n.5.

8. KAPLOW \& SHAVELL, NON-INDIVIDUALISTIC, supra note 2 , at 1.

9. A welfarist theory must ignore such information. BOADWAY \& BRUCE, supra note 4 , at 143 (noting that under welfarism, "information about how the utility levels are obtained is irrelevant for determining how the social states should be ordered").

10. Suppose, for example, we want to rank two alternatives, $x$ and $y$, neither of which Paretodominates the other. If faimess information indicates that $x$ is the unique fairness optimum under $F$, then both $F^{*}$ and $F^{* *}$ would rank $x$ over $y$. If, however, fairness information indicates instead that $y$ is the unique fairness optimum, then both $F^{*}$ and $F^{* *}$ would rank $y$ over $x$, even if the utility information regarding the alternatives is unchanged.

11. LOUS KaPLOW \& STEVEN SHAVEll, ANY NON-Welfarist METHOD OF POLICY ASSESSMENT Violates THE PaReto PRinciple (Harvard Law Sch., Public Law and Legal Theory Working Paper No. 3, 1999) (revised draft of KAPLOW \& SHAVELL, NONINDIVIDUALISTIC, supra note 2), forthcoming in $109 \mathrm{~J}$. POL. ECON. (2001). 
indeed, as I have shown, cannot) show that "any" such theory violates the Pareto principle. They show only that some non-welfarist theories violate the Pareto principle. In particular, they can show only that non-welfarist theories that comply with independence and continuity conditions over an unrestricted domain must violate the Pareto principle. ${ }^{12}$

In their reply to my article, Kaplow and Shavell deny that either $F^{*}$ or $F^{* *}$ is " a Pareto-conflict-free notion that is not solely based on individuals' well-being." ${ }^{13}$ The basis for their claim is obscure, but Kaplow and Shavell apparently seek to expand their definition of welfarism to include $F^{*}$ and $F^{* *}$ and accordingly add new restrictions to their definition of fairness. In their reply, Kaplow and Shavell suggest for the first time that their notion of welfarism would allow rankings to depend on more information than just individual utility levels. First, they assert that rankings under their framework could depend on information about individuals, so that social choices "could give more to Joe because he is tall and less to Jill because her preferences are objectionable." ${ }^{14}$ Even assuming that the definition of welfarism allows such information about the characteristics of individuals to be morally relevant, this concession is still insufficient to bring $F^{*}$ and $F^{* *}$ within the definition. If $F$ is liberal consequentialism, for example, then $F^{*}$ and $F^{* *}$ require not information about individuals but rather information about the effect of each alternative on the type of utility enjoyed by each individual. Under either $F^{*}$ or $F^{* *}$, it is insufficient to know that Jill has objectionable preferences. We must also know the degree to which each alternative satisfies her personal preferences.

Perhaps Kaplow and Shavell now intend to include such information about alternatives within their framework. They suggest, for example, that they do not intend to include any fairness regarding distribution in their definition of fairness. ${ }^{15}$ In their prior writing, however, they exclude only "some" distributive concerns, namely those based "solely on individuals" well-being." 16 They contrast these welfarist concerns with "theories bearing on the just distribution of income... not based solely on

12. Each condition is necessary for the weak Pareto principle to imply welfarism. If we relax the requirement of continuity, for example, then we can add a faimess principle as a tiebreaker to an otherwise welfarist theory. The result is a fair Paretian theory that complies with independence conditions. Similarly, if we relax the requirement of independence, then we can produce a fair Paretian theory of social welfare that is continuous in individual utilities. Consider a theory that produces standard downward-sloping social indifference curves in utility space. This theory of social welfare would be both continuous and Paretian. If we make the shape and position of these curves in utility space a function of faimess information, however, as the shape and position of the partitions under $F^{*}$ or $F^{* *}$ are, then the underlying theory of social welfare is a faimess theory.

13. Kaplow \& Shavell, supra note 5, at 246.

14. Id. at $237 \mathrm{n} .2$.

15. Id. at 246 n. 24 .

16. Kaplow \& Shavell, Conflict, supra note 2, at 67 (citing the theory that "marginal utility of income is greater for the poor" as an example of an idea "based only on individuals' wellbeing”); see also, e.g., KAPLOW \& SHAVELL, HUMAN WELFARE, supra note 2, at 24-26. 
individuals' well-being," which "can be shown sometimes to . . conflict with the Pareto principle." 17 Indeed, they claim specifically that their formal proof of a conflict between the Pareto principle and fairness "encompasses distributive theories that are not based only on individuals" utilities" as subject to their claim. ${ }^{18}$ Thus, because the distributive fairness in $F^{*}$ and $F^{* *}$ is based not only on individuals' utilities but also on other information, they are among the fairness theories supposedly subject to their claim regarding a conflict with the Pareto principle.

Kaplow and Shavell can bring $F^{*}$ and $F^{* *}$ within their definition of welfarism only by modifying that definition to allow in any fairness information that can affect the distribution of utility. After all, the fairness criterion $F$ could give weight to any fairness notion criticized by Kaplow and Shavell, including corrective justice and retributive justice. ${ }^{19} \mathrm{I}$ gave liberal consequentialism as only one example of a fairness theory $F$. If $F$ instead is a theory that gives weight to notions like retribution and corrective justice, then so will $F^{*}$ and $F^{* *}$, which make the fairness optimum under $F$ relevant for ranking alternatives. Thus, $F^{*}$ and $F^{* *}$ would allow in considerations that Kaplow and Shavell specifically seek to exclude from our analysis of legal rules. If they seek to define welfarism this broadly, then they have departed radically from the standard definition and left themselves with a notion of welfarism with little content. ${ }^{20}$ Given that they cite the Pareto principle in support of their sweeping attack on all such fairness notions, ${ }^{21}$ their readers may be surprised to find out that Kaplow and Shavell now agree that giving weight to all these notions in functions like $F^{*}$ and $F^{* *}$ is in fact consistent with the Pareto principle. That is, regardless of what Kaplow and Shavell mean by "welfarism," my article demonstrates that the Pareto principle by itself cannot provide support for their general recommendation that legal policy should be evaluated using a framework "under which assessments of policies depend exclusively on their effects on individuals' well-being." 22

17. Kaplow \& Shavell, Conflict, supra note 2 , at 67 n.9.

18. Id. (citing KAPLOW \& SHAVELL, NON-INDIVIDUALISTIC, supra note 2).

19. Id. at $70-71$.

20. The concept that remains, which apparently includes $F^{*}$ and $F^{* *}$ as well as utilitarianism, would seem to be mere Paretianism. If so, then Kaplow and Shavell's claim reduces to a tautology: The Pareto principle implies the Pareto principle.

21. KAPLOW \& SHAVELl, HUMAN WelFare, supra note 2, at 44.

22. Id. at 454. Presumably for this reason, Kaplow and Shavell state in their reply that allowing any distributive principle into their definition of welfarism violates "the spirit of some of our arguments." Kaplow \& Shavell, supra note 5, at 237 n.2. This statement leaves unclear precisely what they mean to include in their notion of welfarism.

In their reply, Kaplow and Shavell also invoke their "symmetric case," which they claim is "by itself sufficient to establish that there is a conflict between any notion of faimess and the Pareto principle." Id. at 239 (emphasis added). This case, however, at most demonstrates a potential conflict between a crude fairness principle like $F$ and the Pareto principle. Under either $F^{*}$ or $F^{* *}$, if all individuals in the world were somehow to find themselves in this imaginary 
To derive this position from the Pareto principle, Kaplow and Shavell must make continuity and independence assumptions that are themselves controversial. ${ }^{23}$ In their reply, they seek to defend these assumptions as requirements for "logical consistency." ${ }^{24}$ Neither axiom, however, is logically required.

Kaplow and Shavell criticize the discontinuity implied by $F^{*}$ or $F^{* *}$ by noting that "no matter how much unfairness is involved, it can be outweighed by the tiniest amount of administrative cost savings." ${ }^{25}$ Under $F^{*}$ or $F^{* *}$, however, costs would trump unfairness only in the context of a Pareto improvement, when everyone would agree to waive their right to the fairness optimum. Alienable rights to fairness imply that neither $F^{*}$ nor $F^{* *}$ would give any weight to unfairness, regardless "how much" unfairness is at stake, if everyone prefers to override fairness concerns. As long as the Pareto principle is not at stake, however, fairness concerns would trump any welfarist concern.

Similarly, Kaplow and Shavell declare that violations of independence are "absurd," but offer little reason for the reader to agree. ${ }^{26}$ Theories like $F^{*}$ and $F^{* *}$ violate independence because they take alienable rights to fairness seriously. In Sen's example,$^{27}$ these theories would give $P$ the right not to read a book (that is, we would choose $o$ over $p$ ), unless he waives this right. Whether $P$ chooses to waive this right may in turn depend on whether an alternative like $l$ (in which $L$ reads the book) is feasible, because $l$ would be the fairness optimum, so that $L$ can credibly threaten to make $l$ our social choice. ${ }^{28}$ If the feasibility of $l$ implies that $P$ would agree to alternative $p$,

symmetric case, they could unanimously agree to waive their rights to the fairness optimum under $F$. This demonstration does not prevent a Paretian from applying faimess principles in the real world, in which individuals do not find themselves in that symmetric setting. Thus, I question the relevance of this hypothetical and the conclusions that Kaplow and Shavell seek to draw from it. See Chang, supra note 1, at 190 n.69.

23. Kaplow and Shavell seek to distinguish their independence assumption from that of Kenneth Arrow by noting that their assumption does not share all of the controversial features of Arrow's. Kaplow \& Shavell, supra note 5, at 243 n.17. Like Arrow's assumption, however, Kaplow and Shavell's assumption includes the controversial feature of "pairwise choice," which "means that in socially ranking any pair of candidates a device cannot respond to information about other candidates." Alfred F. MACKAY, ARROW'S THEOREM: THE PARADOX OF SOCIAL CHOICE 93 (1980). Theorists have questioned this particular aspect of Arrow's assumption. Id. at 92 (noting that pairwise choice "does not appear to have much intrinsically to recommend it"); DENNIS C. MUELlER, PUBliC CHOICE II 394 (1989) (questioning the "normative value" of the assumption that "social choices made in pairwise comparisons"" should determine " the entire social ordering"” (quoting KENNETH J. ARROW, SOCIAL. CHOICE AND INDIVIDUAL VALUES 28 (2d ed. 1963))).

24. Kaplow \& Shavell, supra note 5, at 238.

25. Id. at 242 .

26. Id. at 244 .

27. See Chang, supra note 1, at 196-98 (citing Amartya Sen, The Impossibility of a Paretian Liberal, 78 J. POL. ECON. 152, 155 (1970)).

28. The feasibility of the third alternative would be relevant only if it represents a fairness optimum (like $l$ ) and thus represents an alternative to which individuals are entitled. Only then 
then we would rank $p$ above $o$ as long as $l$ is a feasible alternative. ${ }^{29}$ I leave it to the reader to decide whether this respect for alienable rights, which makes the feasibility of third alternatives morally relevant, is "absurd," as Kaplow and Shavell claim. ${ }^{30}$

Kaplow and Shavell also complain that a procedure like $F^{* *}$ would require an infinite number of steps to generate the modified rankings. ${ }^{31}$ This feature of $F^{* *}$, however, is not necessary to prove the possibility of a fair Paretian. Other counterexamples to Kaplow and Shavell's claim do not require an infinite number of steps to complete..$^{32}$ Furthermore, one would

would the alternative be a credible threat as a social choice that would induce individuals to waive their rights to object to a Pareto superior alternative (like $p$ ).

Nevertheless, Kaplow and Shavell complain that the feasibility of alternatives may be costly to determine or may be influenced by the expenditures of individuals. Kaplow \& Shavell, supra note 5, at 244-45. Theories like $F^{*}$ or $F^{* *}$, however, could take these costs into account. For example, if $L$ can credibly threaten to make $l$ feasible, say, by leaming the language used in the book in question, then $l$ is already feasible in the relevant sense. Thus, if everyone prefers that we choose $p$ rather than requiring $L$ to make $l$ feasible (because it would not be chosen anyway), then under $F^{*}$ or $F^{* *}$ we would do so.

Similarly, the decision to investigate the feasibility of $l$ would itself be a social choice. Under liberal consequentialism, the cost of this investigation would itself be morally relevant. First, an individual like $L$, who is entitled to the alternative in question if it is feasible, would be entitled to this investigation only if it is not too costly compared with the expected increase in the satisfaction of personal preferences under $l$. Second, if the feasibility of $l$ is so likely that everyone would prefer to choose $p$ without an investigation of $l^{\text {'s }}$ feasibility, then under $F^{*}$ or $F^{* *}$ we would do so.

29. Thus I suggest that our ranking of a pair of feasible alternatives may depend on the feasibility of a third alternative. I also criticize the suggestion that the infeasibility of a hypothetical alternative implies that it would not be desirable if it were feasible. Chang, supra note 1, at 202 . Kaplow and Shavell's reply to my article confuses these two distinct suggestions regarding the moral relevance of feasibility. Kaplow \& Shavell, supra note 5, at 243-44 \& n. 19.

30. To support their claim, Kaplow and Shavell offer a hypothetical that supposedly illustrates the problems raised by violations of the independence condition. Id. at $245 \mathrm{n} .21$. Their example, however, is disturbing only because it assumes an unreasonable faimess theory, one that gives "Bill, the richest ... person in the society," the right to veto a move that would alleviate the "misery" of "every other person," who is "on the brink of starvation." Id. Here Kaplow and Shavell attack a straw man; they derive an unreasonable result by making an unreasonable assumption. A reasonable faimess theory, like liberal consequentialism, would make "starvation" of so many people morally relevant in the determination of the fairness optimum. Bill, like everyone else in society, would be entitled to the faimess optimum, which would consider the personal preferences of everyone, not to the "starvation" regime described by Kaplow and Shavell.

31. Id. at 246. They further claim that $F^{* *}$ is "impossible," because if we assign "real numbers" to the ranks under $F$, and the ranks fully occupy the real line, then there is no room left on the real line to allow the creation of more ranks. Id. at $246 \& \mathrm{n} .25$. They incorrectly assume, however, that the creation of more ranks requires the assignment of new numbers on the real line. Consider, for example, the addition of a tiebreaking rule, which can create new ranks notwithstanding the fact that the old ranks fully occupied the real line. The "leximin" rule, for example, multiplies ranks through the use of such tiebreakers. Chang, supra note 1, at 225 n.198. Similarly, under $F^{* *}$, we can replace rank 10 with ranks $10 \mathrm{a}, 10 \mathrm{~b}$, and $10 \mathrm{c}$. We can transfer the alternatives remaining in rank 10 to rank $10 \mathrm{~b}$, place alternatives that rank higher than 10 but lower than any higher rank in $10 \mathrm{a}$, and place altematives that rank lower than 10 but higher than any lower rank in 10c.

32. For example, if we find the possibility of infinite iterations in theory to be a disturbing prospect, then we can replace step (4) of $F^{* *}$ with the following: "(4a) To rank alternatives within these newly created sets, apply a welfarist principle." The resulting theory would still be a 
have to perform an infinite number of steps under $F^{* *}$ only in theory. In practice, given the costliness of gathering and analyzing information, for reasons explained in my article, a belief in $F^{* *}$ is almost certain to imply the same choices one would make under the "crude" fairness theory $F^{33}$ Thus, the practical implications of $F^{* *}$ suggest that the Pareto principle requires very little change from the social choices we would make under criterion $F^{34}$ This implication of $F^{* *}$ makes it all the more surprising that Kaplow and Shavell now seek to embrace this theory within their definition of welfarism, because $F^{* *}$ undermines their claim that the Pareto principle implies that we should ignore the many fairness principles that may enter criterion $F$.

Finally, Kaplow and Shavell ask "what criteria" we should use to launder preferences in a theory like liberal consequentialism. ${ }^{35} \mathrm{I}$ believe that the question of precisely what theory of preference laundering we should embrace is an important issue that is well worth exploring further in the future. ${ }^{36} \mathrm{I}$ do not need to defend any particular answer to this question,

fairness theory, because it would still require fairness information in step (1). That is, the fairness optimum under $F$ would remain the presumptive social optimum, which could be trumped only by a Pareto improvement and not by any other alternative favored by a welfarist theory.

33. Chang, supra note 1, at 230-32. I argue that given the constraints imposed by scarce resources, the constrained optimum under $F^{*}$ or $F^{* *}$ is likely to be the fairness optimum under $F$. In their reply, Kaplow and Shavell question this proposed focus on the faimess optimum under $F$, basing their critique on the incorrect assumption that this optimum must be "identified in a literally perfect, precise manner." Kaplow \& Shavell, supra note 5, at 247 n.26. A fairness criterion $F$ like liberal consequentialism would take the costs of policy analysis into account in selecting the social optimum. Thus, one would maximize $F$ only as best one could given the scarcity of resources. In support of their claim, Kaplow and Shavell cite the fact that $F^{*}$ and $F^{* *}$ violate continuity and independence. Id. at 247. These features of $F^{*}$ and $F^{* *}$ would not be relevant to the identification of the faimess optimum under $F$. If $F$ is liberal consequentialism, then it could satisfy Kaplow and Shavell's continuity and independence assumptions.

34. As Kaplow and Shavell note, "in reality, it will rarely be the case that one legal rule will literally make everyone better off than will another legal rule." Kaplow \& Shavell, Conflict, supra note 2 , at 72 .

35. Kaplow \& Shavell, supra note 5, at 248. Kaplow and Shavell ask, for example, about "external preferences that have socially desirable effects," such as "disapprobation" that "deters individuals from improper behavior." Id. These effects, however, merely suggest that we may wish to encourage these external preferences for their instrumental value in promoting the satisfaction of personal preferences. It does not follow that we should count the satisfaction of these external preferences as instrinsically valuable components of social welfare.

Kaplow and Shavell also criticize my use of the term "instrinsically immoral" as conclusory. Id. at $248 \mathrm{n} .28$ (quoting Chang, supra note 1, at $189 \mathrm{n.67}$ ). The footnote that they quote, however, uses that term as a conclusion only after first explaining the distinctiwon between "purely self-regarding preferences" and "inherently discriminatory preferences" such as " those reflecting overt racial hostility" or " "racially selective sympathy." Chang, supra note 1, at 189 n.67 (quoting Paul Brest, The Supreme Court, 1975 Term-Foreword: In Defense of the Antidiscrimination Principle, 90 HARV. L. REV, 1, 8 (1976)).

36. For example, is the sadist's pleasure of "seeing ... victims suffer" a personal preference that ought to count? Kaplow \& Shavell, supra note 5, at $248 \mathrm{n} .28$. To the extent that this sadist's preferences require that the victims actually suffer, however, this pleasure derives from an external preference. The component that is purely personal could be satisfied by actors pretending to suffer. Thus, the pleasure of seeing a snuff film would be objectionable, but the pleasure of seeing violence depicted using actors and special effects would not. In any event, I am open to 
however, to disprove Kaplow and Shavell's claim regarding the Pareto principle. My counterexample is sufficient to prove the possibility of a fair Paretian regardless of what theory of preference laundering one may use to construct the fairness criterion $F$. Although I have offered some views on preference laundering, the identification of the ideal fairness theory is an achievement that I do not claim to have accomplished.

Kaplow and Shavell also ask "who gets to choose" which preferences we launder ${ }^{37}$ One can just as easily ask who gets to decide the right answer to any moral or political question. Who decides whether to embrace welfarism or fairness theories? If we all endorse welfarism, then who decides which welfarist theory to embrace? ${ }^{38}$ The answer is that we each decide the answer to these questions, as individuals engaged in the process of moral reasoning. We can seek to persuade one another of one theory or another, but ultimately we all must make such judgments for ourselves. ${ }^{39}$ In this spirit, I have presented a liberal theory of social welfare for the reader's consideration. I offer it as only one option on the menu of theories from which the reader may choose, depending on the reader's own moral intuitions.

arguments that there may exist some personal preferences that ought not to count. I have only criticized the suggestion that we must "exclude all personal preferences that derive from moral or political views." Chang, supra note 1 , at 194 (emphasis added).

37. Kaplow \& Shavell, supra note 5, at 248.

38. Although Kaplow and Shavell endorse welfarism, they do not defend any particular functional form for the social welfare function.

39. Perhaps Kaplow and Shavell mean to ask what legal and political institutions we should erect in order to make social choices. These issues, such as what constitution, what rights for individuals against the government, what democratic procedures, and what rules for judicial review we should adopt, are questions that each individual must answer according to that individual's moral and political beliefs. How to make social choices in the absence of any consensus on moral and political philosophies is itself a problem that we each must consider according to our own moral and political principles. Each of us may endorse the same electoral processes or doctrines of judicial restraint using entirely different moral and political theories. 